\title{
IMPACT OF HARMONIZATION ON THE IMPLICIT TAX RATE OF CONSUMPTION
}

\author{
Andrea Feher, Bogdan Virgil Condea, Daniela Harangus*
}

\begin{abstract}
This paper brings to the foreground an indicator rather less used in specialized studies - the implicit tax rate of consumption - as an effective tax rate of consumption.

In an empirical analysis, we try to analyse the impact of the main determinants on the implicit tax rate of consumption. The analysis is based on the panel technique in order to show the impact of tax harmonization on consumer taxation at EU27, EU15 and NMS12 levels, testing three hypotheses:

(1) the implicit tax rate of consumption is directly influenced by the economic growth rate;

(2) the effects of harmonization are more pronounced in the new EU member states; (3) during an economic crisis, the budget deficit and public debt determine changes in the implicit tax rate.
\end{abstract}

Keywords: value added tax, implicit tax rate, budgetary deficit, public debt, econometric modelling

JEL Classification: F36, F37, F38

\section{Introduction}

This paper grants special importance to consumption taxation. These taxes prove to be increasingly valuable fiscal policy instruments for EU member states. By far, the VAT was the most effective tax during the crisis to reduce budget deficits. Also, harmonization efforts focus primarily on this tax, and at the member state level, we can state that the VAT has become the most important tax.

The theoretical perspectives of harmonization are reflected in the development of consumption taxation regarding the evolution of rates applied to both the value added tax and excise duties. The results of harmonization are reflected in the impact of the evolution of these rates on the revenues collected from the above taxes, which are at the foreground of the harmonization process.

A study that captures the importance of the VAT was conducted by Slintáková and Klazar (2010), who present the changes in the VAT rate encountered in the Czech Republic as a result of the harmonization process, such as a change from $23 \%$ in 1993 , when this tax was introduced, to $19 \%$ in 2004 , when it joined the EU.

* Andrea Feher, Banat University of Agricultural Sciences and Veterinary Medicine

"King Michael I of Romania" in Timisoara, Faculty of Management and Rural Tourism; Romania (andreafeher@usab-tm.ro);

Bogdan Virgil Condea, “Aurel Vlaicu” University of Arad, Faculty of Economic Sciences, Romania (bogdan.condea@uav.ro);

Daniela Harangus, "Aurel Vlaicu” University of Arad, Faculty of Economic Sciences, Romania

(daniela.harangus@uav.ro). 
The econometric analysis that we intend to achieve is centred on the impact of determinants on the implicit tax rate of consumption.

Tax harmonization is a process of adjusting national tax systems in accordance with certain common interests. Tax harmonization is a process of eliminating tax barriers and existing discrepancies between different tax systems across the European Union, but also globally (Mara, 2013:159).

The EC Treaty sets out the fundamental rules on tax harmonization:

- $\quad$ according to Art. 90, it is forbidden to apply to imported products indirect taxes superior to those applied to similar indigenous products;

- according to Art. 91 it is forbidden, when exporting products to other member states, to grant refunds of internal taxes which are higher than the taxes the products in question were actually subject to;

- according to Art. 93, the harmonization of indirect taxes is based on the unanimous decision of the member states, to the extent that such harmonization is necessary to ensure the functioning of the internal market.

The most relevant indicator able to express the outcome of the harmonization process is the implicit tax rate of consumption. This implicit quota is calculated by Eurostat as a ratio between all revenues from consumption taxes and the global consumption registered in a state over a one-year period.

The methodology for calculating this indicator is established by the European Commission and is presented in detail in the annual document Taxation Trends in the European Union. According to the 2013 document, the methodology for calculating the implicit tax rate of consumption is primarily based on the classification of taxes on consumption and then on the actual calculation. Consumption taxes are defined as taxes levied on transactions between final consumers and producers of final goods destined for consumption.

The implicit tax rate of consumption is divided into four categories. This classification refers only to the nominator meaning that revenues are divided according to the category of consumption tax which they come from as follows:

- VAT: part of the implicit share related to the VAT;

- energy: this subcategory includes all taxes on energy consumption represented mainly by mineral oil excise, taxes on electricity and similar taxes;

- $\quad$ tobacco and alcohol: these include taxes on alcohol and tobacco;

- residual part: all remaining consumption taxes fall into this subcategory; they are obtained as difference of the total.

The implicit tax rate of consumption is an indicator that captures the evolution of both collected revenues and the rates applied differently, such as excise duties, which can be considered an effective tax rate. It is quite difficult to analyse the evolution of rates especially in the case of excises when we have different rates depending on the product, expressed as a fixed amount in euros and in percentage. 
In this study we will perform an analysis of the outcomes of the harmonization process in the member states of the European Union. To see these results we use an aggregate indicator provided by the Eurostat database: the implicit tax rate of consumption.

The analysis will be carried out at a global level for all Member States of the European Union, for the period 1995-2011 so as to capture the main trends that marked consumption taxes. Implicit tax rate of consumption can be considered a correspondent for an effective tax rate of consumption. The usefulness of this indicator comes especially in the context where a single tax rate is not used in the case of excise duties and the VAT, having rates differentiated by product category.

The evolution of the implicit tax rate of consumption at the EU27 level shows significant differences between the period of economic growth up to 2007 (marked by an explosion in consumption and, at the same time, by an increase in indirect tax rates, especially excise duties, particularly for new member states that joined in 2004 and 2007) and the economic crisis (marked by a sudden decline in consumption that induced a rapid erosion revenues from consumption taxes). However, the year 2010 marks an ascending trend as a result of measures to increase VAT and excise rates.

In foreign specialized literature there are numerous approaches to the tax harmonization process both conceptually and from an empirical perspective. We find various definitions of the harmonization process and its typology in Nerudova (2008), and arguments in favour of the harmonization necessity in James and Oats (1998).

Conconi et al. (2008) present different scenarios of harmonization, and authors such as Razin and Sadka (1991), Persson and Tabellini (1995), Turnovsky (1997), Rodrik and Van Ypersele (2001) and Fourçans (2006) analyse the implications of tax harmonization from an empirical perspective based on descriptive and econometric studies.

The article is divided into two subchapters: the first subchapter presents the descriptive analysis and description of variables used in the econometric study, and the second one describes the calculation methodology. At the end of the article, the findings of the study are presented.

\section{Econometric Modelling of Consumption Tax Determinants in the Context of the Tax Harmonization Process}

\subsection{Descriptive analysis and description of variables}

Within this analysis, we will perform a modelling of the consumption tax determinants in the context of the harmonization and tax coordination process from 1995 to 2011. For the econometric modelling, we used both macroeconomic variables with a certain impact on consumption taxation and fiscal variables, included in designing tax policy. These variables are explained in the following table.

Before building the econometric model and testing the hypotheses, we present the descriptive statistics of the variables used for the three aggregates EU-27, EU-15 and NMS-12. 
Table 1 | Variables of the Econometric Model

\begin{tabular}{|l|l|l|l|}
\hline Variables & \multicolumn{1}{|c|}{ Description } & Source & Acronym \\
\hline Economic growth rate & $\%$ change in GDP, calculated from year to year & Eurostat & $d G D P$ \\
\hline GDP per capita & Euro & AMECO & GDPC \\
\hline Investments & $\%$ of GDP & Eurostat & $I$ \\
\hline Price index & Inflation rate \% & Eurostat & IP \\
\hline Unemployment rate & $\%$ & Eurostat & Ur \\
\hline Population & Millions of inhabitants & Eurostat & P \\
\hline Public revenues & Fiscal pressure \% of GDP & Eurostat & $R$ \\
\hline Public expenditures & $\%$ of GDP & Eurostat & E \\
\hline Budgetary deficit & \% of GDP & Eurostat & BD \\
\hline Public debt & $\%$ of GDP & Eurostat & Db \\
\hline $\begin{array}{l}\text { Implicit tax rate } \\
\text { of consumption }\end{array}$ & $\begin{array}{l}\text { Percentage ratio between all revenues } \\
\text { collected from indirect taxes and global } \\
\text { consumption }\end{array}$ & Eurostat & $I T C$ \\
\hline
\end{tabular}

Source: Authors' synthesis

Table 2 | Descriptive Statistics for EU-27

\begin{tabular}{|l|c|c|c|c|c|c|c|c|c|c|c|}
\hline & dGDP & GDPC & $\boldsymbol{I}$ & $\boldsymbol{I P}$ & $\boldsymbol{U r}$ & $\boldsymbol{P}$ & $\boldsymbol{R}$ & $\boldsymbol{E}$ & $\boldsymbol{B D}$ & $\boldsymbol{D} \boldsymbol{b}$ & ITC \\
\hline $\begin{array}{l}\text { Numbers } \\
\text { of obser- } \\
\text { vations }\end{array}$ & 451 & 450 & 459 & 453 & 455 & 455 & 459 & 459 & 459 & 453 & 450 \\
\hline Min. & -17.73 & $5,179.35$ & 8.30 & -1.68 & 2.30 & 0.37 & 29.60 & 30.29 & -31.31 & -86.78 & 11.10 \\
\hline Max. & 11.74 & $82,363.63$ & 39.96 & $1,061.21$ & 22.90 & 82.52 & 57.81 & 65.64 & 6.94 & 160.81 & 34.20 \\
\hline Average & 2.81 & $23,965.16$ & 22.28 & 7.34 & 8.56 & 18.17 & 42.08 & 44.90 & -2.82 & 39.30 & 21.16 \\
\hline $\begin{array}{l}\text { Standard } \\
\text { deviation }\end{array}$ & 3.59 & $12,225.85$ & 4.69 & 50.87 & 3.98 & 22.40 & 6.62 & 6.61 & 3.74 & 33.71 & 4.39 \\
\hline
\end{tabular}

Source: Eurostat processed data

We have the greatest differences between old and new member states regarding the development level and economic growth rate in the period considered. The average GDP per capita is almost double in the EU-15 compared with the average in the NMS-12 (Eurostat; Feher et al., 2017) but the average economic growth rate is much higher in the NMS-12. 
Table 3 | Descriptive Statistics for EU-15

\begin{tabular}{|l|c|c|c|c|c|c|c|c|c|c|c|}
\hline & dGDP & GDPc & $\boldsymbol{I}$ & $\boldsymbol{I P}$ & $\boldsymbol{U r}$ & $\boldsymbol{P}$ & $\boldsymbol{R}$ & $\boldsymbol{E}$ & $\boldsymbol{B D}$ & $\boldsymbol{D} \boldsymbol{b}$ & $\boldsymbol{I T C}$ \\
\hline $\begin{array}{l}\text { Numbers } \\
\text { of obser- } \\
\text { vations }\end{array}$ & 255 & 255 & 255 & 255 & 255 & 255 & 255 & 255 & 255 & 251 & 250 \\
\hline Min. & -8.35 & $13,988.15$ & 10.51 & -1.68 & 2.30 & 0.41 & 32.09 & 30.29 & -31.31 & -86.78 & 12.50 \\
\hline Max. & 10.92 & $82,363.63$ & 30.98 & 8.91 & 22.90 & 82.52 & 57.81 & 65.64 & 6.94 & 160.81 & 34.20 \\
\hline Average & 2.30 & $30,673.30$ & 20.83 & 2.21 & 7.76 & 25.53 & 45.23 & 47.46 & -2.23 & 42.06 & 22.12 \\
\hline $\begin{array}{l}\text { Standard } \\
\text { deviation }\end{array}$ & 2.71 & $11,370.35$ & 3.15 & 1.23 & 3.54 & 26.12 & 6.54 & 6.49 & 4.08 & 40.65 & 4.78 \\
\hline
\end{tabular}

Source: Eurostat processed data

Table 4 | Descriptive Statistics for NMS-12

\begin{tabular}{|c|c|c|c|c|c|c|c|c|c|c|c|}
\hline & $d G D P$ & $G D P C$ & $I$ & IP & Ur & $P$ & $R$ & $E$ & $B D$ & $D b$ & ITC \\
\hline $\begin{array}{l}\text { Numbers } \\
\text { of obser- } \\
\text { vations }\end{array}$ & 196 & 195 & 204 & 198 & 200 & 200 & 204 & 204 & 204 & 202 & 200 \\
\hline Min. & -17.73 & $5,179.35$ & 8.30 & -1.22 & 2.60 & 0.37 & 29.60 & 32.90 & -12.80 & 3.70 & 11.10 \\
\hline Max. & 11.74 & $29,595.39$ & 39.96 & $1,061.21$ & 20.51 & 38.65 & 52.90 & 55.80 & 4.20 & 108.30 & 29.60 \\
\hline Average & 3.48 & $15,192.98$ & 24.09 & 13.95 & 9.58 & 8.79 & 38.15 & 41.70 & -3.54 & 35.88 & 20.00 \\
\hline $\begin{array}{l}\text { Standard } \\
\text { deviation }\end{array}$ & 4.40 & $6,338.43$ & 5.59 & 76.54 & 4.27 & 10.78 & 4.19 & 5.24 & 3.12 & 21.88 & 3.50 \\
\hline
\end{tabular}

Source: Eurostat processed data

\subsection{Research methodology}

In order to achieve the econometric analysis, we used the panel technique to test the impact of tax harmonization on consumption at the level of the EU-27, EU-15 and NMS-12. The panel-based methodology gives us a global picture of all the EU member states as a compact group in which some common characteristics and trends are identified for the entire analysed period of time.

The analysis tested some assumptions related to the tax harmonization process that was carried out differently in the old EU member states and the new member states which acceded in 2004 and 2007. Our study uses data provided by the Eurostat database for the period 1995-2011. The econometric modelling will pursue the impact of macroeconomic variables, as well as the impact of fiscal variables on consumption taxes, to observe their influence on the background of the tax harmonization process.

The analysis is structured over two periods. The first period considered in the study is 1995-2011. We considered this time period because we have data for all the 27 member states and we consider that the implications of the harmonization process are reflected 
in this time horizon, given that many of the former communist states, between 1990 and 1995, began to adopt in their national legislations taxes such as the VAT and excise duties.

A second period considered in the study is 2007-2011, the time of the global financial crisis, marked by extensive changes in tax policy, reflected in the evolution of tax rates as well as some significant changes in budgetary revenue collection.

The econometric study is based on the estimation of panel data using the EViews software. The aggregate for which the analysis was conducted was the group of the 27 member states in order to have an overview of the situation across the European Union. In a subsequent step, we performed an econometric modelling separately for the old member states (EU-15) and for the new member states (NMS-12) to highlight the differences between the two groups of countries marked by different evolutions of the harmonization process and the tax policy promoted.

The regression applied to panel data is different from a simple cross-sectional regression or from one using time series because it has a double index on its variables. The $i$ index shows the cross-sectional dimension and the $t$ index the temporal one (Baltagi, 2008).

As an estimation method we chose the method of least squares (LS). There are several types of models for panel data. The main distinction is between models with fixed effects (FE) and ones with random effects (RE). In models with fixed effects, the error component can be correlated with the regressions; however, the hypothesis that there is no correlation between the two is still maintained. In RE models it is assumed that the error is totally random, a stronger hypothesis involving its lack of correlation with the regressions (Baum, 2001).

In order to decide whether a FE model or a RE one is more appropriate, we can perform a Hausman test. The Hausman principle can be applied to all problems of testing hypotheses in which two estimators are involved. In the specific case of the panel data model, it is known that the FE estimator is consistent in the RE model as well as in the FE one. In the FE model it is also efficient. On the other hand, the RE estimator cannot be used in the FE model, being efficient by its construction in the RE model only (Kunst, 2009).

To test the appropriate form of the econometric model and to determine whether the random-effects model is more appropriate than the fixed-effects model, the Hausman test can be applied (Conconi et al., 2008). The test is based on the difference between the estimates obtained based on the fixed-effects model and those of the randomeffects model. In the case of a null hypothesis, the Hausman test statistics follow an $X^{2}$ distribution with the number of degrees of freedom equal to the total number of regressions in the model.

We also used the Hausman test in the case of the model estimated in this study to choose between the method of least squares with fixed effects and with random effects; in most cases, the Hausman test showed that the most relevant method is the one with fixed effects; only in one case we applied the random-effects model. 


\section{Empirical Results}

Hypotheses tested:

H1: The implicit tax rate of consumption is directly influenced by the economic growth rate.

H2: The harmonization effects are more pronounced in new member states (since the actual rate is not correlated with macroeconomic variables).

H3: During an economic crisis, budgetary deficit and public debt cause changes in the implicit tax rate.

These hypotheses have been chosen to analyse from a new perspective the consumption taxation, which plays an important role in a country's economic situation.

Based on these hypotheses, we constructed the equations of the econometric model, including macroeconomic variables and alternatively fiscal variables that cannot be introduced into an equation simultaneously to avoid multicollinearity.

Table 5 | Equations of the Model

\begin{tabular}{|l|l|l|}
\hline Method & \multicolumn{1}{|c|}{ Equations of the model } & Equations \\
\hline $\begin{array}{l}\text { Panel Least Square } \\
\text { (Fixed/random effects) }\end{array}$ & $\begin{array}{l}I T C_{t}=a_{1}+a_{2} * d G D P_{t}+a_{3} * I_{t}+a_{4} * I P_{t}+a_{5} * U r_{t}+ \\
+a_{6} * P_{t}+a_{7} * \underline{R}_{t}\end{array}$ & (1) \\
\hline $\begin{array}{l}\text { Panel Least Square } \\
\text { (Fixed/random effects) }\end{array}$ & $\begin{array}{l}I T C_{t}=a_{1}+a_{2} * d G D P_{t}+a_{3} * I_{t}+a_{4} * I P_{t}+a_{5} * U r_{t}+ \\
+a_{6} * P_{t}+a_{7} * \underline{E}_{t}\end{array}$ & (2) \\
\hline $\begin{array}{l}\text { Panel Least Square } \\
\text { (Fixed/random effects) }\end{array}$ & $\begin{array}{l}I T C_{t}=a_{1}+a_{2} * d G D P_{t}+a_{3} * I_{t}+a_{4} * I P_{t}+a_{5} * U r_{t}+ \\
+a_{6} * P_{t}+a_{7} * B D_{t}+a_{8} * D B_{t}\end{array}$ & (3) \\
\hline
\end{tabular}

Source: Authors' processing

The results obtained from the regression estimates are synthesized in the tables below. The dependent variable for all the regressions is the implicit tax rate of consumption.

The significant determinants of consumption taxation in all member states are investments and the global tax burden. In terms of economic growth, the implicit tax rate of consumption will increase as the receipts from these taxes increase and rate increases were also registered in terms of excise duties, as in the case of the VAT, but only in isolated cases (the first hypothesis of the model is confirmed). Investments have the same direct impact on the growth of ITC because they represent a consumption of durable goods or fixed capital.

The unemployment rate is indirectly correlated with ITC, because if the unemployment rate increases, the consumption revenues are reduced and there appears a tendency to reduce the regressive indirect taxes in certain situations by extending reduced rates. The price index does not have a significant impact and population was introduced as a control variable, which in all cases seems to have an indirect impact on ITC (it is quite difficult to explain this impact). 
The level of tax burden appears to have a direct correlation as indirect taxation is an important component of the tax burden. In the case of first regression equation, the model is first explained in a proportion of $57 \%$ by means of independent variables.

Econometric modelling for the NMS-12 highlights results quite similar with those for the EU-27, except that the economic growth rate is not a significant factor (hypothesis 2 is confirmed) whereas the ITC for these countries change due to the requirements of the harmonization process. Thus, this statistical evidence is confirmed by the econometric model.

Table 6 | Tax Determinants ITC, 1995-2011

\begin{tabular}{|c|c|c|c|c|c|c|}
\hline \multirow[b]{3}{*}{$\begin{array}{l}\text { Independent } \\
\text { variables }\end{array}$} & \multicolumn{6}{|c|}{$\begin{array}{l}\text { Dependent variable: } \\
\text { Implicit Tax Rate of Consumption (ITC) }\end{array}$} \\
\hline & \multicolumn{2}{|c|}{ EU-27 } & \multicolumn{2}{|c|}{ NMS-12 } & \multicolumn{2}{|c|}{ EU-15 } \\
\hline & $\begin{array}{l}\text { (1) } \\
\text { LS }\end{array}$ & $\begin{array}{l}(2) \\
\text { LS (FE) }\end{array}$ & $\begin{array}{l}\text { (3) } \\
\text { LS }\end{array}$ & $\begin{array}{l}(4) \\
\text { LS (FE) }\end{array}$ & $\begin{array}{l}\text { (5) } \\
\text { LS }\end{array}$ & $\begin{array}{c}(6) \\
\text { LS (FE) }\end{array}$ \\
\hline$d G D P$ & $\begin{array}{l}0.08^{* *} \\
(2.07)\end{array}$ & $\begin{array}{l}-0.009 \\
(-0.41)\end{array}$ & $\begin{array}{l}-0.05 \\
(-1.27)\end{array}$ & $\begin{array}{c}0.01 \\
(0.46)\end{array}$ & $\begin{array}{l}0.27^{* * *} \\
(3.49)\end{array}$ & $\begin{array}{c}0.04 \\
(1.26)\end{array}$ \\
\hline I & $\begin{array}{l}0.07^{* * * *} \\
(2.94)\end{array}$ & $\begin{array}{l}0.08^{* * *} \\
(3.05)\end{array}$ & $\begin{array}{l}0.14^{* * *} \\
(4.85)\end{array}$ & $\begin{array}{l}0.03 \\
(0.91)\end{array}$ & $\begin{array}{l}-0.04 \\
(-0.82)\end{array}$ & $\begin{array}{l}0.03 \\
(0.76)\end{array}$ \\
\hline IP & $\begin{array}{l}-0.001 \\
(-0.43)\end{array}$ & $\begin{array}{l}-0.003^{* * *} \\
(-2.90)\end{array}$ & $\begin{array}{l}-0.002 \\
(-1.25)\end{array}$ & $\begin{array}{l}-0.002 \\
(-1.47)\end{array}$ & $\begin{array}{c}0.22 \\
(1.12)\end{array}$ & $\begin{array}{c}0.09 \\
(1.25)\end{array}$ \\
\hline Ur & $\begin{array}{l}-0.07^{* *} \\
(-2.18)\end{array}$ & $\begin{array}{l}-0.048 \\
(-1.20)\end{array}$ & $\begin{array}{l}-0.002 \\
(-0.08)\end{array}$ & $\begin{array}{l}-0.11^{* *} \\
(-2.47)\end{array}$ & $\begin{array}{l}-0.19^{* * *} \\
(-3.39)\end{array}$ & $\begin{array}{l}-0.008 \\
(-0.18)\end{array}$ \\
\hline$P$ & $\begin{array}{c}-0.06^{* * *} \\
(-10.09)\end{array}$ & $\begin{array}{l}-0.28^{* * *} \\
(-3.15)\end{array}$ & $\begin{array}{l}-0.007 \\
(-0.50)\end{array}$ & $\begin{array}{l}-3.27^{* * *} \\
(-4.07)\end{array}$ & $\begin{array}{l}-0.05^{* * *} \\
(-7.25)\end{array}$ & $\begin{array}{c}-0.23^{* * *} \\
(-3.10)\end{array}$ \\
\hline$R$ & $\begin{array}{l}0.49^{* * *} \\
(39.87)\end{array}$ & $\begin{array}{l}0.33^{* * *} \\
(9.81)\end{array}$ & $\begin{array}{l}0.44^{* * *} \\
(22.33)\end{array}$ & $\begin{array}{l}0.52^{* * *} \\
(11.90)\end{array}$ & $\begin{array}{l}0.54^{* * *} \\
(26.69)\end{array}$ & $\begin{array}{l}-0.02 \\
(-0.39)\end{array}$ \\
\hline Hausman Test & - & 0.0080 & - & 0.0013 & - & 0.0001 \\
\hline Observations & 438 & 438 & 188 & 188 & 250 & 250 \\
\hline R-squared & 0.57 & 0.91 & 0.61 & 0.84 & 0.58 & 0.95 \\
\hline
\end{tabular}

Note: The models are based on the method of least squares (LS) and fixed effects (FE).

$t$-statistics in parentheses; *** Significant at 1\%; ${ }^{* *}$ Significant at $5 \%$; Significant at $10 \%$;

The data are used for the period 1995-2011.

Source: Synthesis of results provided by EViews.

In Table 7, we have the same regression equation, only the tax burden (tax revenues as \% of GDP) was replaced with budgetary expenditures expressed as the share in GDP (the true measure of tax burden according to some authors, because at some time budgetary deficit will also be financed on account of taxes). The significance of ITC determinants 
does not change significantly compared with the previous table. The introduction of public expenditures reveals that their increase will entail ITC increases in the need to finance these public expenditures. This result was also confirmed by the results of the study conducted by Onaran et al. (2011).

Table 7 | Budgetary Determinants of ITC, 1995-2011

\begin{tabular}{|c|c|c|c|c|c|c|}
\hline \multirow[b]{3}{*}{ Independent variables } & \multicolumn{6}{|c|}{$\begin{array}{l}\text { Dependent variable: } \\
\text { Implicit Tax Rate of Consumption (ITC) }\end{array}$} \\
\hline & \multicolumn{2}{|c|}{ EU-27 } & \multicolumn{2}{|c|}{ NMS-12 } & \multicolumn{2}{|c|}{ EU-15 } \\
\hline & $\begin{array}{l}\text { (1) } \\
\text { LS }\end{array}$ & $\begin{array}{c}(2) \\
\text { LS (FE) }\end{array}$ & $\begin{array}{l}\text { (3) } \\
\text { LS }\end{array}$ & $\begin{array}{c}\text { (4) } \\
\text { LS (FE) }\end{array}$ & $\begin{array}{l}\text { (5) } \\
\text { LS }\end{array}$ & $\begin{array}{c}(6) \\
\text { LS (FE) }\end{array}$ \\
\hline$d G D P$ & $\begin{array}{l}0.26^{* * *} \\
(5.02)\end{array}$ & $\begin{array}{l}0.009 \\
(0.36)\end{array}$ & $\begin{array}{c}0.05 \\
(1.02)\end{array}$ & $\begin{array}{l}0.09^{* *} \\
(2.25)\end{array}$ & $\begin{array}{l}0.53^{* * *} \\
(5.72)\end{array}$ & $\begin{array}{l}0.01 \\
(0.48)\end{array}$ \\
\hline I & $\begin{array}{l}0.10^{* * *} \\
(3.35)\end{array}$ & $\begin{array}{l}0.11^{* * *} \\
(3.61)\end{array}$ & $\begin{array}{l}0.19^{* * *} \\
(5.90)\end{array}$ & $\begin{array}{l}0.07 \\
(1.54)\end{array}$ & $\begin{array}{c}0.05 \\
(0.82)\end{array}$ & $\begin{array}{l}0.005 \\
(0.11)\end{array}$ \\
\hline IP & $\begin{array}{l}0.002 \\
(0.62)\end{array}$ & $\begin{array}{c}-0.004^{* * *} \\
(-2.90)\end{array}$ & $\begin{array}{l}-4.86 \\
(-0.002)\end{array}$ & $\begin{array}{l}-0.002 \\
(-1.11)\end{array}$ & $\begin{array}{c}0.17 \\
(0.76)\end{array}$ & $\begin{array}{c}0.03 \\
(0.47)\end{array}$ \\
\hline Ur & $\begin{array}{l}-0.19^{* * *} \\
(-5.07)\end{array}$ & $\begin{array}{l}-0.01 \\
(-0.44)\end{array}$ & $\begin{array}{l}0.006 \\
(0.16)\end{array}$ & $\begin{array}{l}-0.07^{* *} \\
(-1.24)\end{array}$ & $\begin{array}{l}-0.40^{* * *} \\
(-5.59)\end{array}$ & $\begin{array}{c}0.04 \\
(0.99)\end{array}$ \\
\hline$P$ & $\begin{array}{l}-0.06^{* * *} \\
(-8.58)\end{array}$ & $\begin{array}{l}-0.32^{* * *} \\
(-3.25)\end{array}$ & $\begin{array}{l}-0.02 \\
(-1.51)\end{array}$ & $\begin{array}{l}-2.38^{* *} \\
(-2.41)\end{array}$ & $\begin{array}{l}-0.06^{* * *} \\
(-6.59)\end{array}$ & $\begin{array}{l}-0.17^{* *} \\
(-2.26)\end{array}$ \\
\hline$E$ & $\begin{array}{l}0.46^{* * *} \\
(31.94)\end{array}$ & $\begin{array}{l}0.06^{* *} \\
(2.50)\end{array}$ & $\begin{array}{c}0.37^{* * *} \\
(19.06)\end{array}$ & $\begin{array}{l}0.29^{* * *} \\
(6.02)\end{array}$ & $\begin{array}{l}0.50 * * * \\
(21.32)\end{array}$ & $\begin{array}{l}-0.10^{* * *} \\
(-3.82)\end{array}$ \\
\hline Hausman Test & - & 0.008 & - & 0.020 & - & 0.003 \\
\hline Observations & 438 & 438 & 188 & 188 & 250 & 250 \\
\hline R-squared & 0.41 & 0.89 & 0.51 & 0.77 & 0.42 & 0.95 \\
\hline
\end{tabular}

Note: The models are based on the method of least squares (LS) and fixed effects (FE). $t$-statistics in parentheses; ${ }^{* * *}$ Significant at $1 \%$; ${ }^{* *}$ Significant at $5 \%$; ${ }^{*}$ Significant at $10 \%$; The data are used for the period 1995-2011.

Source: Synthesis of results provided by EViews.

In the third model presented in the Table 8 , the tax variables introduced consisted of budgetary deficit and public debt expressed as a percentage of GDP. Both are significant for the regressions built.

Public debt is significantly correlated with ITC. Public debt can have a positive effect or a negative one, because it can serve, on the one hand, as a substitute for taxes: when taxes are reduced, expenditures must be financed through debt; on the other hand, there is a loan effect: as the public debt increases, higher taxes are required to pay the debt (Onaran et al., 2012). By resorting to an increase in public debt to provide a lower level of income, a period of financial stability is created, so public debt can be considered to help maintain 
a low level of taxation for that period, but will have as a secondary effect a further increase in taxes to cover the rise in public debt. One of the reasons why public debt is increased when a surplus of income is needed is the impossibility to increase income sources either by applying higher rates or by stimulating greater consumption.

Table 8 | Budgetary Determinants (budget deficit and public debt) of ITC, 1995-2011

\begin{tabular}{|c|c|c|c|c|c|c|}
\hline \multirow[b]{3}{*}{$\begin{array}{l}\text { Independent } \\
\text { variables }\end{array}$} & \multicolumn{6}{|c|}{$\begin{array}{l}\text { Dependent variable: } \\
\text { Implicit Tax Rate of Consumption (ITC) }\end{array}$} \\
\hline & \multicolumn{2}{|c|}{ EU-27 } & \multicolumn{2}{|c|}{ NMS-12 } & \multicolumn{2}{|c|}{ EU-15 } \\
\hline & $\begin{array}{l}\text { (1) } \\
\text { LS }\end{array}$ & $\begin{array}{c}\text { (2) } \\
\text { LS (FE) }\end{array}$ & $\begin{array}{l}\text { (3) } \\
\text { LS }\end{array}$ & $\begin{array}{c}\text { (4) } \\
\text { LS (RE) }\end{array}$ & $\begin{array}{l}(5) \\
\text { LS }\end{array}$ & $\begin{array}{c}(6) \\
\text { LS (FE) }\end{array}$ \\
\hline dGDP & $\begin{array}{l}-0.10^{*} \\
(-1.77)\end{array}$ & $\begin{array}{l}-0.04^{*} \\
(-1.77)\end{array}$ & $\begin{array}{l}-0.20^{* * *} \\
(-3.02)\end{array}$ & $\begin{array}{l}-0.10^{* *} \\
(-2.37)\end{array}$ & $\begin{array}{l}-0.004 \\
(-0.06)\end{array}$ & $\begin{array}{c}0.02 \\
(0.80)\end{array}$ \\
\hline I & $\begin{array}{l}-0.17^{* * *} \\
(-4.25)\end{array}$ & $\begin{array}{l}0.08^{* * *} \\
(2.59)\end{array}$ & $\begin{array}{l}0.39 * * * \\
(6.82)\end{array}$ & $\begin{array}{l}0.01^{* *} \\
(2.44)\end{array}$ & $\begin{array}{l}-0.54^{* * *} \\
(-9.26)\end{array}$ & $\begin{array}{l}-0.03 \\
(-0.59)\end{array}$ \\
\hline IP & $\begin{array}{l}-0.007^{* *} \\
(-2.19)\end{array}$ & $\begin{array}{l}-0.005^{* * *} \\
(-3.75)\end{array}$ & $\begin{array}{c}-0.007^{* *} \\
(-2.33)\end{array}$ & $\begin{array}{l}-0.005^{* * *} \\
(-2.73)\end{array}$ & $\begin{array}{l}-0.24 \\
(-1.51)\end{array}$ & $\begin{array}{c}0.06 \\
(0.94)\end{array}$ \\
\hline Ur & $\begin{array}{l}-0.19 * * * \\
(-4.34)\end{array}$ & $\begin{array}{c}0.02 \\
(0.68)\end{array}$ & $\begin{array}{c}0.06 \\
(1.19)\end{array}$ & $\begin{array}{l}0.01 \\
(0.17)\end{array}$ & $\begin{array}{l}-0.19 * * * \\
(-3.79)\end{array}$ & $\begin{array}{c}0.04 \\
(0.91)\end{array}$ \\
\hline$P$ & $\begin{array}{l}-0.04^{* * *} \\
(-5.45)\end{array}$ & $\begin{array}{c}-0.23^{* *} \\
(-2.39)\end{array}$ & $\begin{array}{l}0.006 \\
(0.27)\end{array}$ & $\begin{array}{l}0.007 \\
(0.08)\end{array}$ & $\begin{array}{l}-0.07^{* * *} \\
(-10.59)\end{array}$ & $\begin{array}{l}-0.15^{* *} \\
(-1.97)\end{array}$ \\
\hline$D b$ & $\begin{array}{l}-0.04^{* * *} \\
(-7.31)\end{array}$ & $\begin{array}{l}0.0005 \\
(0.08)\end{array}$ & $\begin{array}{c}0.06 * * * \\
(4.85)\end{array}$ & $\begin{array}{l}-0.003 \\
(-0.22)\end{array}$ & $\begin{array}{l}-0.03^{* * *} \\
(-7.71)\end{array}$ & $\begin{array}{l}-0.005 \\
(-3.82)\end{array}$ \\
\hline$B D$ & $\begin{array}{l}0.21^{* * * *} \\
(3.69)\end{array}$ & $\begin{array}{l}0.09^{* * * *} \\
(3.43)\end{array}$ & $\begin{array}{c}0.13 \\
(1.40) \\
\end{array}$ & $\begin{array}{c}0.18^{* *} \\
(2.55) \\
\end{array}$ & $\begin{array}{l}0.30^{* * * *} \\
(5.33) \\
\end{array}$ & $\begin{array}{l}0.09^{* * * *} \\
(3.42) \\
\end{array}$ \\
\hline Hausman Test & - & 0.011 & - & 0.630 & - & 0.007 \\
\hline Observations & 432 & 432 & 186 & 186 & 246 & 246 \\
\hline R-squared & 0.36 & 0.89 & 0.22 & 0.13 & 0.71 & 0.95 \\
\hline
\end{tabular}

Note: The models are based on the method of least squares (LS) and fixed effects (FE).

$t$-statistics in parentheses; ${ }^{* * *}$ Significant at $1 \%$; ${ }^{*}$ Significant at $5 \%$; $*$ Significant at $10 \%$;

The data are used for the period 1995-2011.

Source: Synthesis of results provided by EViews.

Thus, the expected sign of this variable is not clear a priori. The model regressions confirm this uncertainty; public debt is indirectly correlated with ITC, except in the case of the NMS-12, where the increase in debt clearly involves an increase in indirect taxation to cover it.

The budget deficit is correlated in all cases indirectly with this implicit tax rate of consumption (appears in the model with the "+" sign, but considering that the deficit is highlighted with the "-" sign, for which there is an indirect correlation). We anticipate this result as if the deficit decreases; this is explained by the increase in the implicit tax rate of consumption (De Grauwe, 2013). We expect results more relevant for the crisis period of this determinant variable. 
The same models with the component regression equations were tested for the subperiod 2007-2011, a period marked by the effects of the economic crisis, particularly reflected by a drastic decrease in consumption, but also by a generalized increase in VAT rates in member states. In this context, we will estimate regressions to observe significant determinants and major changes compared to the overall period. The results of the regression equations are found in the tables forming the Appendix.

A first change is the insignificant impact of the economic growth rate on the ITC. In the case of the study conducted with the first two independent variables: incomes and expenditures, the investments are positively correlated with the ITC; when public debt and the budget deficit are included in the equation, the investments are indirectly correlated with the ITC. When there is an increase in revenue, their surplus may be directed towards investments that are intended to stimulate consumption, while in the case of public debt, investments are indirectly linked because an increase in public debt requires greater productivity in the allocation of financial resources which a country has, and most of the time the investments are passed second.

Public revenues and expenditures remain significant and with a direct impact on ITC. As we anticipate, they become more significant, and public debt retains both directions of influence, as previously.

This econometric analysis has certain limitations because we could have included as determinant factor also political or institutional factors or even variables regarding underground economy. Another possible direction of econometric testing is on welfare state models to strengthen the robustness of the results and increase the degree of customization taking into account the specific of each model.

\section{Conclusions}

The theoretical perspectives of harmonization are reflected in the evolution of consumption taxation as regards the evolution of applied rates of the value added tax as well as excise duties. Harmonization results are reflected in the impact of the evolution of these quotas on revenues collected from the above taxes, which are at the forefront of the harmonization process.

As consumption taxation represents a significant weight in the gross domestic product, we chose an empirical approach to consumption taxation modelling at the European Union level seen as a unitary space (EU-27), as well as a unit of two aggregates (EU-15 and NMS-12) that can be delimited due to differences regarding the development of component states, as well as concerning the tax systems and the tax harmonization and coordination that was carried out in recent years. An interesting study would have been the demarcation of the euro area by the rest of the member states, but we consider more relevant the analysis of the old and new member states also from the perspective of the development level.

A decisive element between different developments of the new member states and the old ones is represented by tax competition, which determined new member states to build relatively similar tax systems, especially given the fact that they are part 
of the same welfare state model, while the old member states maintained their consumption taxation model.

We can affirm that the new context imposed by the economic recession has led, starting in 2010, to a VAT harmonization "crisis" through a generalized increase in quotas (European Commission, 2018). Under this spectrum, we ask whether a single VAT rate at the EU level, which is above the current average of $21 \%$, but without exceeding the $25 \%$ share, would be a solution that would ensure the sustainability of member states' public finances. Budget deficit and public debts are closely monitored, but they are effects of fiscal policy and, namely, of the measures already implemented. It is difficult to counteract the effect in the absence of an analysis of the causes, or it is certainly tardy to reduce the budget deficit in the context of an economic crisis with low incomes and consistent budget expenditures.

Increasing fiscal pressure to counteract the sovereign debt crisis should also take account of conditions of equity, especially for those with very low incomes, who are affected by the recent increases in taxes, particularly the increase in the VAT rate.

The size of the budget deficit cannot be regarded as a relevant determinant of consumption taxation, as the budget deficit may also change due to other causes that are not dependent on fiscal policy. However, in general, there are two reasons for modifying the budget deficit: the first being the changes in the tax policy; the second being adjusting the level of income to an unchanged tax policy. For example, if investment demand decreases, the income level also decreases, even if there is a fixed rate of tax, and as a result, the budget deficit will increase as the tax revenues to the budget will decrease. Thus, the size of the budget deficit may change as a result of events that have nothing to do with fiscal policy.

The econometric modelling confirmed the assumptions from which we started. The empirical conclusions show a positive and statistically significant impact of consumption tax on economic growth in the absence of public debt and budget deficit. The need to reduce the budgetary deficit and public debt led to an overall increase in the implicit tax rate of consumption, which could be the consequence of the fact that different fiscal policy instruments can lead to opposite effects on economic growth: on the one hand, a greater involvement of the public sector in economy tends to promote growth, but on the other hand, increased indirect taxation negatively affects economic growth.

All the authors have made the same contribution to the elaboration of this article. 


\section{Appendix}

Tax Determinants ITC, 2007-2011

\begin{tabular}{|c|c|c|c|}
\hline \multirow[b]{2}{*}{ Independent variables } & \multicolumn{3}{|c|}{$\begin{array}{l}\text { Dependent variable: } \\
\text { Implicit Tax Rate of Consumption (ITC) }\end{array}$} \\
\hline & EU 27 & NMS 12 & EU 15 \\
\hline$d G D P$ & $\begin{array}{l}0.04 \\
(0.73)\end{array}$ & $\begin{array}{l}-0.003 \\
(-0.06)\end{array}$ & $\begin{array}{c}0.12 \\
(0.86)\end{array}$ \\
\hline$I$ & $\begin{array}{c}0.06 \\
(1.09)\end{array}$ & $\begin{array}{l}0.10^{* *} \\
(2.14)\end{array}$ & $\begin{array}{l}-0.08 \\
(-0.76)\end{array}$ \\
\hline IP & $\begin{array}{l}0.05 \\
(0.40)\end{array}$ & $\begin{array}{l}0.02 \\
(0.22)\end{array}$ & $\begin{array}{l}-0.17 \\
(-0.51)\end{array}$ \\
\hline Ur & $\begin{array}{l}-0.02 \\
(-0.43)\end{array}$ & $\begin{array}{c}0.10 \\
(1.66)\end{array}$ & $\begin{array}{l}-0.13 \\
(-1.20)\end{array}$ \\
\hline$P$ & $\begin{array}{l}-0.07^{* * *} \\
(-6.12)\end{array}$ & $\begin{array}{l}0.01 \\
(0.53)\end{array}$ & $\begin{array}{l}-0.06^{* * *} \\
(-4.49)\end{array}$ \\
\hline $\boldsymbol{R}$ & $\begin{array}{l}0.50^{* * *} \\
(20.40)\end{array}$ & $\begin{array}{l}0.44^{* * *} \\
(15.37)\end{array}$ & $\begin{array}{l}0.59^{* * *} \\
(12.76)\end{array}$ \\
\hline Observations & 135 & 60 & 75 \\
\hline R-squared & 0.49 & 0.60 & 0.54 \\
\hline
\end{tabular}

Note: The models are based on the method of least squares (LS) and fixed effects (FE). $t$-statistics in parentheses; ${ }^{* * *}$ Significant at $1 \%$; ${ }^{* *}$ Significant at $5 \%$; ${ }^{*}$ Significant at $10 \%$; The data are used for the period 2007-2011.

Source: Synthesis of results provided by EViews. 
Budgetary Determinants of ITC, 2007-2011

\begin{tabular}{|c|c|c|c|}
\hline \multirow[b]{2}{*}{ Independent variables } & \multicolumn{3}{|c|}{$\begin{array}{l}\text { Dependent variable: } \\
\text { Implicit Tax Rate of Consumption (ITC) }\end{array}$} \\
\hline & EU 27 & NMS 12 & EU 15 \\
\hline$d G D P$ & $\begin{array}{l}0.13^{*} \\
(1.70)\end{array}$ & $\begin{array}{c}0.08 \\
(1.18)\end{array}$ & $\begin{array}{c}0.20 \\
(1.25)\end{array}$ \\
\hline I & $\begin{array}{l}0.16^{* *} \\
(2.43)\end{array}$ & $\begin{array}{l}0.15^{* *} \\
(2.41)\end{array}$ & $\begin{array}{c}0.17 \\
(1.42)\end{array}$ \\
\hline IP & $\begin{array}{c}0.01 \\
(0.08)\end{array}$ & $\begin{array}{c}0.02 \\
(0.17)\end{array}$ & $\begin{array}{c}0.15 \\
(0.41)\end{array}$ \\
\hline$U r$ & $\begin{array}{l}-0.24^{* * *} \\
(-2.97)\end{array}$ & $\begin{array}{c}0.06 \\
(0.73)\end{array}$ & $\begin{array}{l}-0.55^{* * *} \\
(-4.04)\end{array}$ \\
\hline$P$ & $\begin{array}{l}-0.07^{* * *} \\
(-5.29)\end{array}$ & $\begin{array}{l}-0.02 \\
(-0.65)\end{array}$ & $\begin{array}{l}-0.07^{* * *} \\
(-3.98)\end{array}$ \\
\hline $\boldsymbol{E}$ & $\begin{array}{l}0.45^{* * *} \\
(15.77)\end{array}$ & $\begin{array}{l}0.38^{* * *} \\
(10.66)\end{array}$ & $\begin{array}{l}0.49 * * * \\
(10.04)\end{array}$ \\
\hline Observations & 135 & 60 & 75 \\
\hline R-squared & 0.27 & 0.32 & 0.37 \\
\hline
\end{tabular}

Note: The models are based on the method of least squares (LS) and fixed effects (FE). $t$-statistics in parentheses; ${ }^{* * *}$ Significant at $1 \%$; ${ }^{* *}$ Significant at $5 \%$; ${ }^{*}$ Significant at $10 \%$; The data are used for the period 2007-2011.

Source: Synthesis of results provided by EViews. 
Budgetary Determinants (budget deficit and public debt) of ITC 2007-2011

\begin{tabular}{|l|c|c|c|}
\hline & \multicolumn{3}{|c|}{ Dependent variable: } \\
\hline Implicit Tax Rate of Consumption (ITC) \\
\hline IGDP & EU 27 & NMS 12 & EU 15 \\
\hline I & $\begin{array}{c}0.004 \\
(0.07)\end{array}$ & $\begin{array}{c}-0.25^{* * *} \\
(-3.25)\end{array}$ & $\begin{array}{c}0.06 \\
(0.76)\end{array}$ \\
\hline IP & $\begin{array}{c}-0.30^{* * *} \\
(-4.50)\end{array}$ & $\begin{array}{c}0.15 \\
(1.45)\end{array}$ & $\begin{array}{c}-0.55^{* * *} \\
(-6.00)\end{array}$ \\
\hline Ur & $\begin{array}{c}-0.05 \\
(-0.44)\end{array}$ & $\begin{array}{c}-0.08 \\
(-0.67)\end{array}$ & $\begin{array}{c}-0.28 \\
(-1.25)\end{array}$ \\
\hline P & $\begin{array}{c}-0.27^{* * *} \\
(-3.72)\end{array}$ & $\begin{array}{c}0.11 \\
(1.11)\end{array}$ & $\begin{array}{c}-0.33^{* * *} \\
(-3.75)\end{array}$ \\
\hline D b & $\begin{array}{c}-0.04^{* * *} \\
(-4.17)\end{array}$ & $\begin{array}{c}0.05^{*} \\
(1.67)\end{array}$ & $\begin{array}{c}-0.06^{* * *} \\
(-6.09)\end{array}$ \\
\hline BD & $\begin{array}{c}-0.04^{* * *} \\
(-5.53)\end{array}$ & $\begin{array}{c}0.05^{* *} \\
(2.18)\end{array}$ & $\begin{array}{c}-0.04^{* * *} \\
(5.91)\end{array}$ \\
\hline Observations & $\begin{array}{c}0.28^{* * *} \\
(3.84)\end{array}$ & $\begin{array}{c}0.75^{* * *} \\
(5.45)\end{array}$ & $\begin{array}{c}0.27^{* * *} \\
(3.34)\end{array}$ \\
\hline R-squared & 135 & 60 & 75 \\
\hline
\end{tabular}

Note: The models are based on the method of least squares (LS) and fixed effects (FE). $t$-statistics in parentheses; ${ }^{* *}$ Significant at $1 \%$; ${ }^{*}$ Significant at $5 \%$; $*$ Significant at $10 \%$; The data are used for the period 2007-2011.

Source: Synthesis of results provided by EViews. 


\section{References}

Baltagi, B. H. (2008). Econometric Analysis of Panel Data. Hoboken: John Wiley \& Sons Ltd. ISBN 978-0470744031.

Baum, C. F. (2001). Residual Diagnostics for Cross-section Time Series Regression Models. The Stata Journal, 1(1), 101-104, https://doi.org/10.1177/1536867x0100100108

Conconi, P., Perroni, C., Riezman, R. (2008). Is Partial tax Harmonization Desirable? Journal of Public Economics, 92(1-2), 254-267, https://doi.org/10.1016/j.jpubeco.2007.03.010

De Grauwe, P. (2013). Pool Debt, or Face Dangerous Upheavals across Europe. Europe's World, Spring. [Retrieved 2016-05-05] Available at:

http://www.europesworld.org/NewEnglish/Home_old/Article/tabid/191/ArticleType/ articleview/ArticleID/22076/language/en-US/Default.aspx

Feher, A., Goșa, V., Raicov, M., Haranguș, D., Condea, B. V. (2017). Convergence of Romanian and Europe Union Agriculture - Evolution and Prospective Assessment. Land Use Policy, 67, 670-678, https://doi.org/10.1016/j.landusepol.2017.06.016

Fourçans, A. (2006). Can Tax Competition Lead to a Race to the Bottom in Europe? A Skeptical View. Dep. of Economics, Middlebury, Vt. : Middlebury College.

James, S., Oats, L. (1998). Tax Harmonisation and the Case of Corporate Taxation. Revenue Law Journal, 8(1), Article 3.

Kunst, R-M. (2009). Econometric Methods for Panel Data - Part II. [Retrieved 2016-07-09] Available at: http://homepage.univie.ac.at/robert.kunst/panels2e.pdf

Mara, E. R. (2013). Public Finances between Competition and Tax Harmonization. Cluj-Napoca: Risoprint Publishing House.

Nerudova, D. (2008). Tax Harmonization in EU. [Retrieved 2016-04-07] Available at: http://mibes. teilar.gr/e-books/2008/ Nerudova\%2090-109.pdf

Onaran, O., Boesch, V., Leibrecht, M. (2011). How Does Globalization Affect the Implicit Tax Rates on Labor Income, Capital Income, and Consumption in the European Union?. Economic Inquiry, 50(4), 880-904, https://doi.org/10.1111/j.1465-7295.2011.00420.x

Persson, T., Tabellini, G. (1995). Double-edged Incentives: Institutions and Policy Coordination. Handbook of International Economics, vol. III. North-Holland, Amsterdam, https://doi. org/10.1016/s1573-4404(05)80018-8

Razin, A., Sadka, E. (1991). International Tax Competition and the Gains from Tax Harmonization. Economics Letters, 37(1), 69-76, https://doi.org/10.1016/0165-1765(91)90245-g

Rodrik, D., Van Ypersele, T. (2001). When Does International Capital Mobility Require Tax Coordination? Journal of International Economics, 54, 57-73.

Slintáková, B., Klazar, S. (2010). Impact of Harmonisation on Distribution of VAT in The Czech Republic. Prague Economic Paper, 19(2), 133-149, https://doi.org/10.18267/j.pep.368

Turnovsky, S. J. (1997). International Macroeconomic Dynamics. Cambridge, MA: MIT Press. ISBN 9780262201117.

Taxation Paper No 38 (2013). Tax Reforms in EU Member States: Tax Policy.

European Commission (2018) . VAT Rates Applied in the Member States of the European Union, Situation at 1st January 2018. Available at: https://ec.europa.eu/taxation_customs/sites/ taxation/files/resources/documents/taxation/vat/how_vat_works/rates/vat_rates_en.pdf 